\title{
PENGUKURAN KEPADATAN IKAN TERUMBU SECARA EX SITU DENGAN METODE AKUSTIK
}

\author{
Deddy Bakhtiar ${ }^{1,2}$, Indra Jaya ${ }^{2}$, Henry M. Manik ${ }^{2}$, Hawis H. Madduppa ${ }^{2}$ \\ 1) Program studi IImu Kelautan, Fakultas Pertanian, Universitas Bengkulu, \\ Bengkulu, Indonesia \\ 2) Departemen IImu dan Teknologi Kelautan, Fakultas Perikanan dan IImu \\ Kelautan IPB, Bogor, Indonesia \\ E-mail :deddybakhtiar@unib.ac.id
}

Received March 2019 , Accepted April 2019

\begin{abstract}
ABSTRAK
Pendugaan kelimpahan ikan terumbu secara akustik masih jarang dilakukan karena tingginya keanekaragaman jenis dalam suatu agregasi sehingga sulit membedakan nilai hambur balik akustik tiap jenis ikan. Oleh karena itu penelitian ini dilakukan dengan tujuan menganalisis hubungan kepadatan ikan Abudefduf saxatilis, Scolopsis lineatus dan Chaetodon trifasciatus terhadap perubahan nilai volume backscattering strength (Sv) kemudian menganalisis tingkat kesesuaian pendugaan kepadatan ikan secara akustik dengan kepadatan ikan sebenarnya melalui pengukuran secara ex situ. Metode yang digunakan adalah metode kurungan untuk pengukuran akustik secara ex situ. Alat yang digunakan dalam pengukuran akustik adalah Echosounder Simrad EK-15 frekuensi 200 $\mathrm{kHz}$. Hasil penelitian menunjukkan nilai hambur balik akustik ketiga ikan terumbu memiliki hubungan yang sangat tinggi dengan kepadatan ikan. Peningkatan kepadatan ikan ikan terumbu akan meningkatkan nilai hambur balik akustik secara linier. Pendugaan kepadatan ikan secara akustik menunjukkan bahwa ikan Abudefduf saxatilis dan ikan Scolopsis lineatus menghasilkan dugaan kepadatan ikan yang sama secara statistik dengan kepadatan ikan yang sebenarnya, sedangkan ikan Chaetodon trifasciatus menghasilkan dugaan kepadatan ikan yang berbeda dan cenderung lebih kecil dari kepadatan ikan yang sebenarnya.
\end{abstract}

Kata kunci : Metode Kurungan, Hambur Balik Akustik, Ikan Terumbu, Pulau Tikus, Ex Situ

\section{ABSTRACT}

MEASUREMENT OF REEF FISH DENSITY USING EX SITU ACOUSTIC METHODS. Estimation of reef fish abundance using acoustic method is still rarely done. High diversity of species in an aggregation impacts on the difficult to distinguish the backscatter value for each species. Therefore, this research was proposed to analyze the relationship of fish density of 
Abudefduf saxatilis, Scolopsis lineatus and Chaetodon trifasciatus for the changing of volume backscattering strength value, then to analyze the conformity of estimate coral fish density comparing with actual reef fish density through ex situ acoustical measurements. Cage method was used in this research for ex situ acoustical measurement using Echosounder Simirad EK-15 $200 \mathrm{kHz}$. The result showed that the acoustic backscattering value of three species had a high relationship with fish density. The density of Abudefduf saxatilis and Scolopsis Lineatus were statistically similar to the actual fish density, while the density of Chaetodon trifasciatus was different and tend smaller than the actual fish density.

Keywords : Cage Method, Acoustic Backscattering, Reef Fish, Tikus Island, Ex Situ

\section{PENDAHULUAN}

Pengelolaan sumberdaya perikanan yang berkelanjutan dan pengelolaan ekosistem yang efektif memerlukan informasi yang akurat tentang dinamika populasi, kelimpahan, dan pola spatio-temporal distribusi spesies ikan yang ditargetkan secara komersial (Zare et al. 2017). Demikian pula Pasaribu (1999) mengungkapkan bahwa untuk menentukan berapa banyak sumberdaya ikan yang dapat dipanen diperlukan informasi tentang berapa besar potensi lestarinya.

Metode yang biasa digunakan untuk menduga distribusi ikan di ekosistem terumbu tropis adalah melalui survei visual atau optik. Namun, keterbatasan cakupan dari metode ini, terutama di perairan yang lebih dalam, membatasi pengetahuan tentang distribusi ikan pada habitat di berbagai resolusi spasial dan luasan. Keterbatasan lainnya pada teknik visual ketika menghitung agregasi besar atau gerombolan ikan (Campanella dan Taylor, 2016). Kemudian Taylor dan Ebert (2012) mengemukakan survei akustik perikanan menawarkan metode yang sesuai untuk menilai dengan cepat agregasi ikan dalam jumlah besar.

Kang et al. (2002) metode hidro-akustik banyak digunakan untuk keperluan memperkirakan kelimpahan stok, memetakan distribusi geografis, dan memperoleh informasi ekologis. Namun teknologi ini masih jarang digunakan untuk menduga kelimpahan ikan di ekosistem terumbu karang, menurut Taylor dan Ebert (2012) alasan kurangnya aplikasi metode akustik dalam ekosistem terumbu karang kemungkinan adanya keterbatasan: 1) keanekaragaman spesies yang tinggi dan masih sedikitnya informasi karakteristik hamburan balik akustik dari spesies ikan terumbu, dan 2) organisme yang dideteksi kadang distribusinya jarang. atau berada di dekat dasar laut yang kompleks dan kasar.

Costa et al. (2014) mengemukakan bahwa distribusi ikan terumbu tidak merata dalam ruang dan waktu pada habitat terumbu karang. Mengidentifikasi dan mengukur agregasi ikan seringkali menjadi prioritas utama bagi pengelolaan wilayah pesisir. 
Keberadaan ikan terumbu yang beragam dan distribusinya yang tidak merata perlu dikaji apakah juga memberikan energi hambur balik akustik yang linear dengan kepadatannya seperti dikemukakan Foote (1983) dalam bentuknya yang paling sederhana, prinsip linearitas menegaskan proporsionalitas dari energi echo total dan kepadatan ikan dalam suatu agregasi.

Jenis ikan terumbu yang umumnya ditemukan di Pulau Tikus sebagian besar adalah dari famili Pomacentridae dengan salah satu jenis yang dominan adalah Abudefduf saxatilis (Bakhtiar et al., 2012; Bakhtiar dan Ta'alidin, 2015). Scolopsis lineatus dari famili Scolopsidae termasuk jenis lainnya yang dominan ditemukan di perairan Pulau Tikus (Bakhtiar et al., 2012) jenis ikan ini memiliki bentuk tubuh memanjang agak dalam, pipih (Russell, 2001). Ikan dari famili Chaetodontidae merupakan jenis ikan yang berfungsi sebagai bioindikator (Madduppa, 2014; ), di perairan Pulau Tikus ikan dari famili ini masih banyak ditemukan salah satunya adalah Chaetodon trifasciatus (Bakhtiar et al., 2012; Bakhtiar dan Ta'alidin, 2015). Jenis ikan ini berbentuk oval (tidak termasuk sirip), tubuh dalam, sangat pipih (Pyle, 2001). Ketiga jenis ikan terumbu yang dominan tersebut menjadi bahan kajian dalam penelitian ini untuk diketahui kepadatannya melalui pendeteksian secara akustik.

Adapun tujuan dari penelitian ini adalah menganalisis hubungan kepadatan ikan Abudefduf saxatilis, Scolopsis lineatus dan Chaetodon trifasciatus (Gambar 1) terhadap perubahan nilai volume backscattering strength (Sv) yang diperoleh secara akustik kemudian menganalisis tingkat kesesuaian pendugaan kepadatan ikan secara akustik dengan kepadatan ikan sebenarnya pada ikan Abudefduf saxatilis, Scolopsis lineatus dan Chaetodon trifasciatus melalui pengukuran secara ex situ.

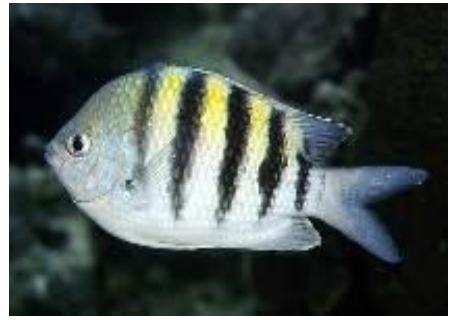

a. Abudefduf saxatilis

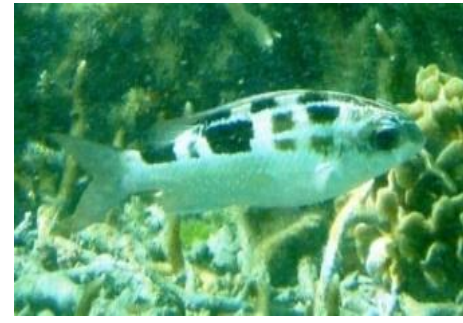

b. Scolopsis lineatus

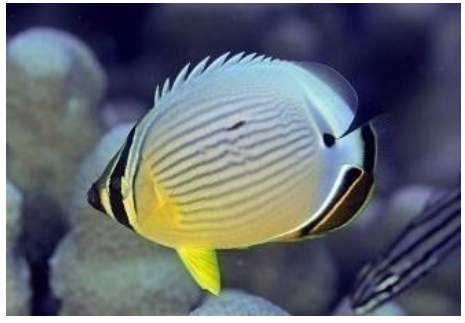

c. Chaetodon trifasciatus

Gambar 1. Jenis ikan terumbu sebagai objek penelitian (sumber gambar: www.fishbase.org)

\section{MATERI DAN METODE}

\section{Waktu dan Tempat Penelitian}

Penelitian ini dilakukan pada bulan November 2017 di perairan Pulau Tikus Kota Bengkulu. Lokasi penelitian dipilih pada perairan yang relatif tenang dan dalam di sekitar Pulau Tikus. 


\section{Rancangan Desain Penelitian}

Rancangan desain penelitian dibuat konstruksi seperti pada Gambar 2. Peralatan utama yang digunakan dalam penelitian ini adalah scientific echosounder dengan frekuensi $200 \mathrm{kHz}$. CPU dan transceiver diletakkan di atas platform apung selama akuisisi data sedangkan transducer diletakkan di bawah permukaan pada kedalaman $50 \mathrm{~cm}$. Kurungan jaring (net cage) yang berukuran 1x1x1 (m) ditempatkan di bawah transduser dengan cara digantung pada kedalaman sekitar $300 \mathrm{~cm}$ sehingga dapat dipastikan ikan akan berada dalam beam akustik.

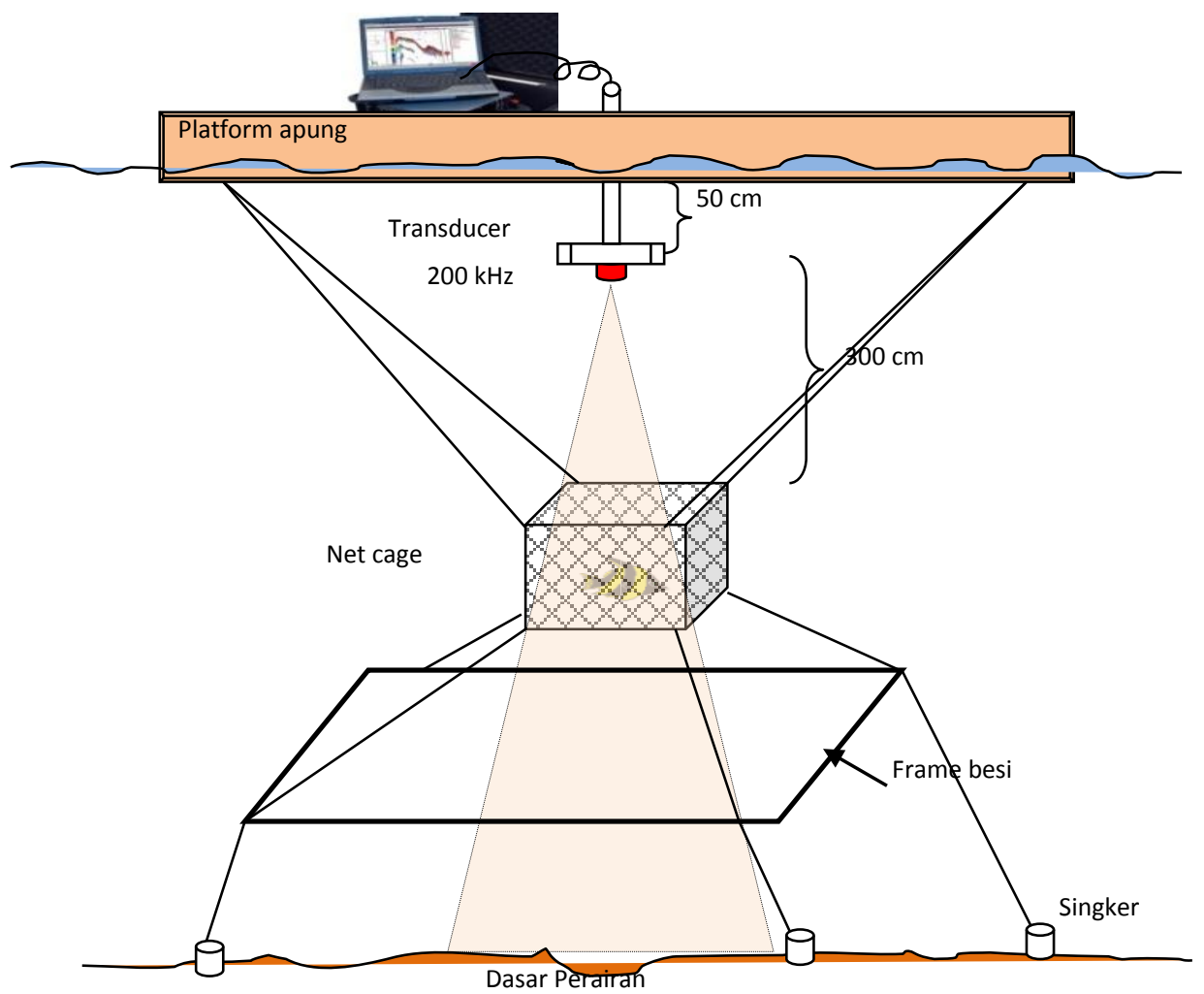

Gambar 2. Sketsa rancangan desain eksperimen (gambar tanpa skala)

\section{Akuisisi Data}

Sebelum melakukan pengukuran dan sounding terhadap ikan penelitian, peralatan akustik yang sudah terpasang terlebih dahulu di kalibrasi. Kalibrasi echosounder dilakukan dengan metode target standar (Foote et al., 1987) menggunakan bola tungsten carbide ukuran diameter $38.1 \mathrm{~mm}$ yang ditempatkan pada sumbu akustik dari transduser. Pengukuran dilakukan di lokasi penelitian pada kedalaman perairan 12 meter dengan kondisi temperatur perairan berkisar $28-31^{\circ} \mathrm{C}$ dan salinitas berkisar $33-38 \%$. Pada penelitian ini, ikan terumbu yang akan diukur ada tiga jenis yaitu ikan Abudefduf saxatilis, Scolopsis lineatus dan Chaetodon trifasciatus (Gambar 1) masing-masing sebanyak 10 ekor. Setiap kelompok jenis ikan terumbu diukur dengan kepadatan yang berbeda yaitu 
2 ekor, 4 ekor, 6 ekor, 8 ekor dan 10 ekor. Namun sebelumnya setiap jenis ikan direkam satu persatu secara akustik untuk mendapatkan karakteristik hambur balik ikan tunggal (target strength, TS)

Akuisisi data dilakukan pertama-tama ikan jenis yang sama dengan kepadatan 2 ekor dimasukan dalam kurungan (cage), dibiarkan selama 15 menit untuk beradaptasi. Selanjutnya dilakukan pengukuran secara akustik dan direkam selama durasi 5 menit. Setelah pengukuran dilanjutkan dengan kepadatan lainnya dan seterusnya hingga seluruhnya terukur dan direkam.

\section{Analisis Data}

Pengolahan data nilai target strength (TS) dan volume backscattering strength (Sv) dilakukan dengan menggunakan software Echoview 8.0. Selanjutnya dianalisis secara statistik menggunakan software Minitab. Adapun analisis yang digunakan antara lain:

\section{Analisis Statistik Deskriptif}

Data Sv yang diperoleh untuk tiap jenis dengan kepadatan yang berbeda kemudian dianalisis lebih lanjut secara deskriptif dengan membuat scatter plot perubahan nilai Sv terhadap peningkatan jumlah kepadatan tiap jenis ikan.

\section{Analisis Hubungan antar Peubah}

Untuk melihat hubungan antar peubah dilakukan Analisis Regresi Linear Sederhana yang akan menghasilkan model hubungan linear antara Sv sebagai peubah tak bebas dan kepadatan ikan sebagai peubah bebas. Untuk mengetahui keeratan hubungan antar peubah tersebut dilakukan Analisis Korelasi Pearson. Model hubungan linear yang telah diperoleh kemudian dilakukan uji kelayakan model dengan menggunakan Uji-F dan dilakukan penilaian keeratan hubungan dengan Koefisien Determinasi $\left(R^{2}\right)$

\section{Analisis Komparatif}

Pada analisis komparatif ini akan dilakukan perbandingan antara kepadatan ikan yang diukur dengan kepadatan ikan hasil pendugaan secara akustik. Nilai kepadatan secara akustik diperoleh dengan perhitungan berikut:

$$
\begin{aligned}
& \rho=\frac{s v}{<\sigma_{b s}>} \quad\left(\mathrm{ind} / \mathrm{m}^{3}\right) \\
& s v=10^{\mathrm{Sv} / 10}\left(\mathrm{~m}^{-1}\right) \\
& <\sigma_{b s}>=10^{T S / 10}\left(\mathrm{~m}^{2}\right)
\end{aligned}
$$


dimana $\rho$ adalah kepadatan ikan secara akustik, sv adalah koefesien volume backscattering dan $\left\langle\sigma_{b s}\right\rangle$ adalah rata-rata backscattering cross section. Nilai TS dan Sv diperoleh dari hasil analisis program Echoview. Analisis komparatif dilakukan menggunakan uji-t untuk menguji kesamaan dua rata-rata dengan hipotesis $\mathrm{Ho}: \mu 1=\mu 2$ dan $\mathrm{Ha}: \mu 1 \neq \mu 2$.

$\mu 1$ adalah rata-rata populasi kepadatan ikan sebenar yang diuji, $\mu 2$ adalah rata-rata populasi kepadatan ikan yang diduga secara akustik. Uji hipotesis dilakukan dengan taraf signifikan $5 \%(p<0.05)$ (Azwar, 2004).

\section{HASIL DAN PEMBAHASAN}

Hubungan nilai volume backscaterring strength (Sv) terhadap kepadatan ikan Abudefduf saxatilis menunjukkan adanya hubungan yang linier seperti ditunjukkan pada Gambar 3 , dalam hal yang sama juga terlihat pada ikan Scolopsis lineatus dan Chaetodon trifasciatus seperti yang ditunjukkan pada Gambar 4 dan Gambar 5.

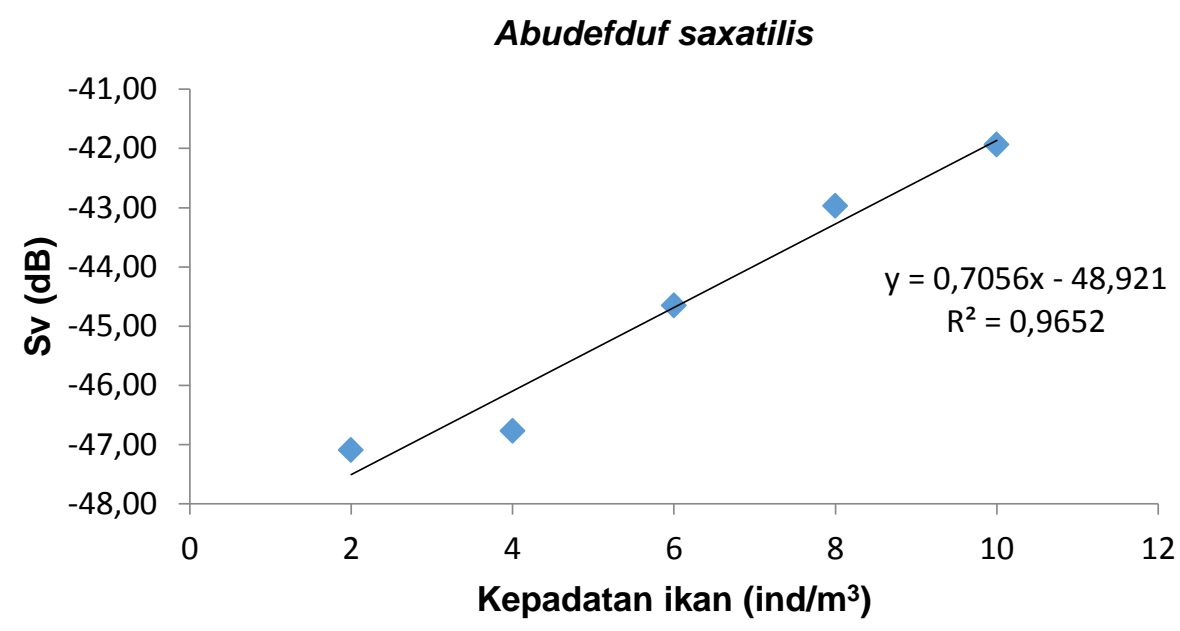

Gambar 3. Model regresi linier hubungan kepadatan ikan Abudefduf saxatilis terhadap nilai volume backscattering strength (Sv)

Scolopsis lineatus

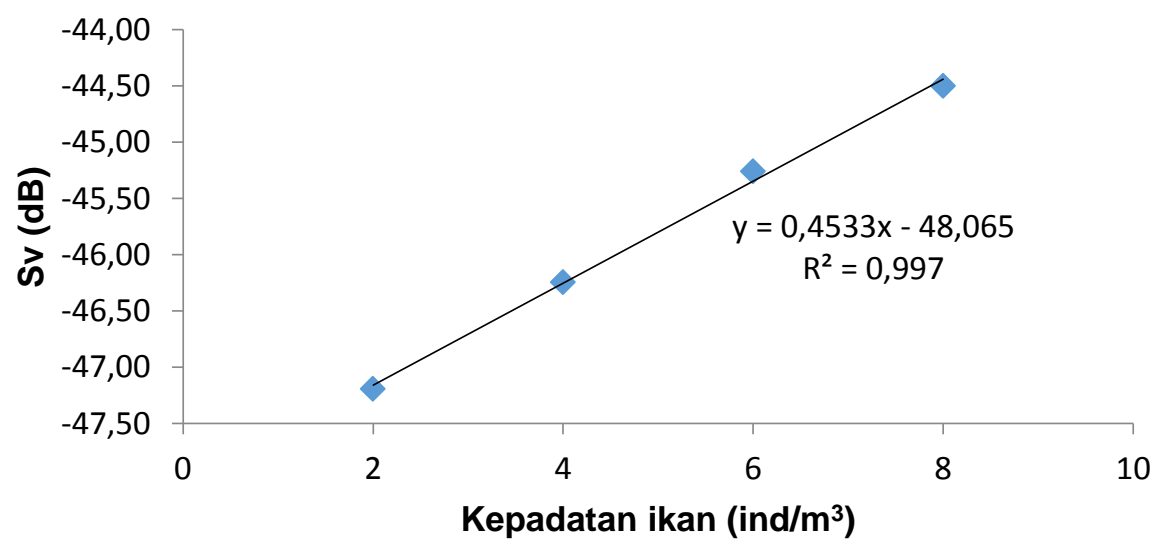

Gambar 4. Model regresi linier hubungan kepadatan ikan Scolopsis lineatus terhadap nilai volume backscattering strength (Sv) 


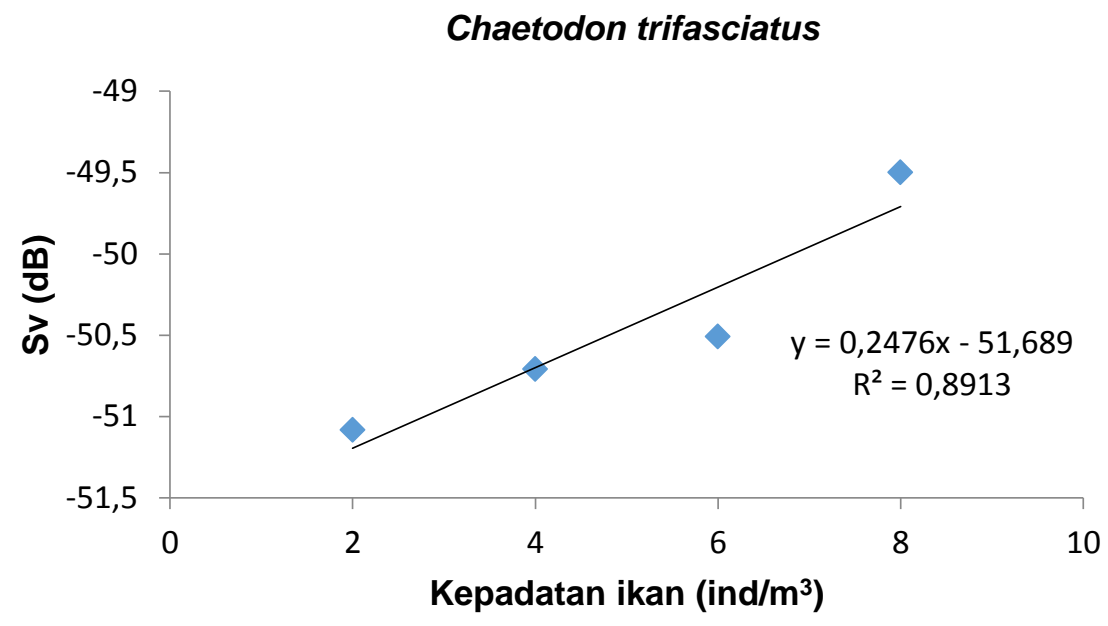

Gambar 5. Model regresi linier hubungan kepadatan ikan Chaetodon trifasciatus terhadap nilai volume backscattering strength (Sv)

Tabel 1 menunjukkan adanya hubungan korelasi yang kuat antara kepadatan ikan terumbu dan perubahan nilai Sv hal ini ditunjukkan dengan tingginya nilai koefisien korelasi $(r)$ ketiga jenis ikan terumbu berkisar antara 0.94 sampai 0.99 , oleh sebab itu hubungan kepadatan ikan dan nilai Sv dapat dikategorikan memiliki korelasi sangat tinggi (Guilford, 1956) dan arah korelasi yang positif menunjukkan semakin tinggi kepadatan ikan akan semakin besar nilai Sv. Manik (2010) juga menjelaskan bahwa scattering volume dan kepadatan ikan memiliki hubungan yang sangat erat. Semakin tinggi nilai densitas ikan maka nilai hamburnya akan semakin tinggi dalam penelitiannya secara terkontrol (ex situ).

Tabel 1. Hasil analisis regresi dan korelasi hubungan kepadatan ikan terumbu terhadap nilai hambur balik akustik (acoustic volume backscattering strength, Sv)

\begin{tabular}{clccc}
\hline No. & \multicolumn{1}{c}{ Jenis Ikan } & $\mathrm{r}$ & $\mathrm{R}^{2}(\%)$ & $\begin{array}{c}\text { Nilai } \mathrm{p} \\
\text { (uji-F) }\end{array}$ \\
\hline 1 & Abudefduf saxatilis & 0.98 & 96.5 & $0.003^{*}$ \\
2 & Scolopsis lineatus & 0.99 & 99.7 & $0.002^{*}$ \\
3 & Chaetodon trifasciatus & 0.94 & 89.1 & $0.056^{\text {ts }}$ \\
\hline
\end{tabular}

Keterangan: $r$ : koefesien korelasi; $R^{2}$ : koefesien determinasi; * ada hubungan yang signifikan pada taraf uji $5 \% \quad(p<0.05)$; ts tidak ada hubungan yang signifikan $(p>0.05)$

Hasil analisis varian dengan uji- $F$ menunjukkan adanya pengaruh kepadatan ikan terhadap nilai Sv dari ikan Abudefduf saxatilis dan Scolopsis lineatus pada taraf uji $5 \%(p<0.05)$ (Tabel 1), jadi peluang kesalahan memutuskan adanya pengaruh kepadatan ikan terhadap nilai Sv adalah kecil dari 5\% (Sugiharto, 2009). Besarnya pengaruh kepadatan 
ikan terhadap nilai Sv juga dapat dilihat dari nilai koefesien determinasi $\left(\mathrm{R}^{2}\right)$ sebesar $96.5 \%$ pada ikan Abudefduf saxatilis yang berarti keragaman nilai Sv $96.5 \%$ ditentukan oleh kepadatan ikan, demikian pula pada ikan Scolopsis lineatus dengan koefesien determinasi sebesar $99.7 \%$.

Berbeda halnya pada ikan Chaetodon trifasciatus, hasil analisis varian menunjukkan nilai $p$ sebesar $0.056(p>0.05)$ yang berarti tidak ada pengaruh yang signifikan antara kepadatan ikan terhadap nilai Sv pada taraf uji 5\% (peluang kesalahan 5\%), walau demikian dapat juga dikatakan kepadatan ikan Chaetodon trifasciatus berpengaruh terhadap nilai Sv secara signifikan dengan menanggung resiko kesalahan sebesar $5.6 \%$ $(p=0.056)$. Signifikan tidaknya statistik yang diuji tergantung kesediaan menanggung resiko pada nilai $p$ yang diperoleh (Azwar, 2004). Peluang kesalahan lebih besar dari $5 \%$ untuk menyatakan adanya hubungan kepadatan ikan terhadap nilai Sv pada ikan Chaetodon trifasciatus ditunjukkan oleh nilai koefesien determinasi sebesar $89.1 \%$ yang berarti ada $10.9 \%$ keragaman lain yang mempengaruhi nilai Sv selain variabel kepadatan ikan. Sumber keragaman ini diduga dari bentuk ikan Chaetodon trifasciatus yang sangat pipih dan tingkah laku renang secara soliter ataupun berpasangan tidak membentuk schooling (Pyle, 2001) juga diduga dari sifat akustik tubuh ikan (faktor g, yang merupakan rasio densitas massa ikan). La et al. (2015) mengemukakan bahwa perbedaan bentuk dan $\mathrm{g}$ lebih rendah dapat menyebabkan Sv lebih rendah. Namun dugaan ini membutuhkan penelitian lebih lanjut untuk memverifikasi sifat akustik tersebut.

Secara umum hasil penelitian ini menunjukkan bahwa peningkatan kepadatan ikan terumbu akan meningkatkan nilai Sv yang diperoleh secara akustik sehingga membentuk hubungan yang linier. Hal ini sesuai dengan prinsip linieritas sebagaimana dikemukakan Foote (1983) bahwa energi echo total proporsional dengan kepadatan ikan dalam suatu agregasi. Demikian pula MacLennan et al. (2004) melaporkan pengukuran pada agregasi dalam kurungan dari ikan gadoid, yang mencakup rentang kepadatan ikan yang lebih luas, $0,05-8,0 \mathrm{~kg} \mathrm{~m}^{2}$, dan tidak ada indikasi penyimpangan signifikan dari linearitas

Hasil analisis komparatif antara kepadatan ikan sebenar dan kepadatan ikan yang diduga secara akustik seperti ditunjukkan Tabel 2, memperlihatkan bahwa hasil dugaan secara akustik pada ikan Abudefduf saxatilis dan ikan Scolopsis lineatus tidak signifikan pada taraf uji $5 \%$ ( $>0.05$ ) hal ini berarti secara statistik ada kesamaan rata-rata kepadatan ikan sebenarnya dan kepadatan ikan yang diduga melalui pendugaan akustik. Manik (2010) mengungkapkan bahwa pendugaan kepadatan akan semakin baik dengan bertambahnya jumlah ikan yang diduga karena pada jumlah tersebut ikan mulai melakukan kegiatan berenang secara bergerombol sehingga nilai hamburan baliknya jauh lebih besar. 
Tabel 2. Hasil analisis komparatif antara kepadatan ikan sebenarnya (ikan uji) dengan kepadatan ikan yang diduga secara akustik

\begin{tabular}{|c|c|c|c|c|c|}
\hline \multirow[b]{2}{*}{ Jenis Ikan } & \multirow[b]{2}{*}{$\begin{array}{c}\text { Kepadatan } \\
\text { ikan uji } \\
\text { (ind/m3) }\end{array}$} & \multirow[b]{2}{*}{$\begin{array}{c}\text { sv } \\
(m-1)^{a)}\end{array}$} & \multicolumn{3}{|c|}{ Kepadatan } \\
\hline & & & $\begin{array}{l}<\sigma_{b s}> \\
(m 2)^{b)}\end{array}$ & $\begin{array}{c}\text { ikan } \\
\text { dugaan } \\
\text { akustik } \\
\left(\text { ind } / \mathrm{m}^{3}\right)^{\mathrm{c}} \text { ) }\end{array}$ & $\begin{array}{l}\text { Nilai } p \\
\text { (uji-t) }\end{array}$ \\
\hline
\end{tabular}

$\begin{array}{lccccc}\begin{array}{l}\text { Abudefduf } \\ \text { saxatilis }\end{array} & 2 & 1.95 \mathrm{E}-05 & 3.83 \mathrm{E}-06 & 5.10 & 0.181^{\text {ts }} \\ & 4 & 2.1 \mathrm{E}-05 & & 5.50 & \\ & 6 & 3.42 \mathrm{E}-05 & & 8.94 & \\ & 8 & 5.05 \mathrm{E}-05 & & 13.18 & \\ & 10 & 6.4 \mathrm{E}-05 & & 16.72 & \end{array}$

Scolopsis

lineatus

$\begin{array}{lllll}2 & 1.91 \mathrm{E}-05 & 6.46 \mathrm{E}-06 & 2.96 & 0.583^{\text {ts }} \\ 4 & 2.37 \mathrm{E}-05 & & 3.68 & \\ 6 & 2.98 \mathrm{E}-05 & & 4.61 & \\ 8 & 3.55 \mathrm{E}-05 & & 5.50 & \end{array}$

Chaetodon

trifasciatus

$\begin{array}{lllll}2 & 7.79 E-06 & 8.6 \mathrm{E}-06 & 0.91 & 0.023^{*} \\ 4 & 8.49 \mathrm{E}-06 & & 0.99 & \\ 6 & 8.89 \mathrm{E}-06 & & 1.03 & \\ 8 & 1.12 \mathrm{E}-05 & & 1.31 & \end{array}$

Keterangan : a) hasil dari persamaan (2); b) hasil dari persamaan (3); ${ }^{c}$ hasil dari persamaan (1); ts : tidak signifikan berbeda secara statistik $(p>0.05),{ }^{*}$ : signifikan berbeda pada pada taraf uji $5 \%(p<0.05)$

Hasil yang berbeda ditunjukkan Tabel 2 pada ikan Chaetodon trifasciatus, nilai $p$ yang diperoleh sebesar $0.023(p<0.05)$ yang berarti terdapat perbedaan yang signifikan antara kepadatan ikan yang sebenarnya dan kepadatan ikan yang diduga secara akustik. Kepadatan yang diduga secara akustik cenderung lebih kecil dari kepadatan sebenarnya dan relatif tidak mengalami perubahan dengan semakin meningkatnya kepadatan ikan yang sebenarnya. Hal ini diduga ada pengaruh dari tingkah laku renang ikan Chaetodon trifasciatus seperti dijelaskan di atas, bahwa ikan ini cenderung berenang soliter ataupun berpasangan tidak membentuk schooling sehingga akan menyebar ke seluruh kolom air. Henderson et al. (2007) mengemukakan bahwa arah berenang ikan dapat memiliki pengaruh besar pada TS, ketika ikan bergerak menjauh dari sumbu akustik, arah berenang memiliki efek yang lebih besar pada TS disebabkan perubahan sudut beam. Kemudian Kang 
et al. (2002) menambahkan bahwa jika school besar dibandingkan dengan beam spreading, Sv yang diperoleh untuk satu ping mewakili kepadatan yang sebenarnya dalam school, namun jika school kecil maka Sv tidak selalu mencerminkan kepadatan secara langsung. Ini karena beam juga " melihat " ruang kosong dan sudut beam setara yang digunakan untuk memperoleh Sv sebagaimana digunakan untuk school besar.

\section{KESIMPULAN}

Nilai hambur balik akustik (volume backscattering strength) ketiga ikan terumbu yaitu Abudefduf saxatilis, Scolopsis lineatus dan Chaetodon trifasciatus, menunjukkan adanya hubungan yang sangat tinggi dengan kepadatan ikan. Peningkatan kepadatan ikan ikan terumbu akan meningkatkan nilai hambur balik akustik secara linier. Hasil pendugaan kepadatan ikan secara akustik pada frekuensi $200 \mathrm{kHz}$ menunjukkan bahwa ikan Abudefduf saxatilis dan ikan Scolopsis lineatus menghasilkan dugaan kepadatan ikan yang sama secara statistik dengan kepadatan ikan yang sebenarnya, sedangkan ikan Chaetodon trifasciatus menghasilkan dugaan kepadatan ikan yang berbeda dan cenderung lebih kecil dari kepadatan ikan yang sebenarnya.

\section{UCAPAN TERIMAKASIH}

Penelitian ini terlaksana atas biaya yang bersumber dari Direktorat Riset dan Pengabdian Masyarakat, Direktorat Jenderal Penguatan Riset dan Pengembangan Kementerian Riset, Teknologi dan Pendidikan Tinggi Tahun Anggaran 2017, untuk itu diucapkan terimakasih atas biaya yang telah diberikan tersebut.

\section{DAFTAR PUSTAKA}

Azwar S. 2004. Signifikan Atau Sangat Signifikan?. Buletin Psikologi UGM, Vol. 13 No.1, Juni 2005. Hal. 38-44.

Bakhtiar D, Djamali A, Arifin Z, Sarwono T. 2012. Struktur Komunitas Ikan Karang di Perairan Pulau Tikus Kota Bengkulu. Prosiding Seminar Nasional Bidang Ilmu-ilmu Pertanian BKS-PTN Wilayah Barat Tahun 2012 Medan 3-5 April 2012, Volume 2:764-772.

Bakhtiar D, Ta'alidin Z. 2015. Kajian Kondisi Terumbu Karang di Pulau Tikus Provinsi Bengkulu. Badan Penelitian, Pengembangan dan Statistik Daerah Provinsi Bengkulu.

Campanella F, Taylor JC. 2016. Investigating acoustic diversity of fish aggregations in coral reef ecosystems from multifrequency fishery sonar surveys . Fisheries Research 181 (2016) : 63-76. 
Costa B, Taylor JC, Kracker L, Battista T, Pittman S. 2014. Mapping Reef Fish and the Seascape: Using Acoustics and Spatial Modeling to Guide Coastal Management. PLoS ONE 9(1): e85555. doi:10.1371/journal.pone.0085555.

Foote KG. 1983. Linearity of fisheries acoustics, with addition theorems. J. Acoust. Soc. Am. 73 (6): 1932-1940.

Foote KG, Knudsen HP, Vestnes GD, MacLennan N, Simmonds EJ, 1987. Calibration of acoustic instruments for fish density estimation: a practical guide. ICES Coop. Res. Rep. 144:1-69.

Guilford JP. 1956. Fundamental Statistics in Psychology and Education. (p. 145). New York: McGraw Hill.

Henderson MJ, Horne JK, Towler RH. 2007. The influence of beam position and swimming direction on fish target strength. ICES Journal of Marine Science, 65: 226-237.

Kang M, Furusawa M, Miyashita K. 2002. Effective and accurate use of difference in mean volume backscattering strength to identify fish and plankton. ICES Journal of Marine Science, 59: 794-804.

La HS, Lee H, Kang D, Lee SH, Shin HC. 2015. Volume backscattering strength of ice krill (Euphausia crystallorophias) in the Amundsen Sea coastal polynya. Deep-Sea Res.II http://dx.doi.org/10.1016/j.dsr2.2015.05.018i.

Madduppa HH, Zamani NP, Subhan B, Aktani U, Ferse SCA. 2014. Feeding behavior and diet of the eight-banded butterflyfish Chaetodon octofasciatus in the Thousand Islands, Indonesia. Environ Biol Fish 97. DOI 10.1007/s10641-014-0225-z.

Manik, HM. 2010. Pengukuran Densitas Ikan Dalam Kondisi Terkontrol Menggunakan Metode Hidroakustik. Di dalam : Syamsuddin S, Sipahutar YH, Saifurridjal, Basith A, Nurbani SZ, Suharto, Siregar AN, Rahardjo S, Hadi RS, Sanova V, editor. Prosiding Seminar Nasional Perikanan Indonesia 2010, 2-3 Desember 2010. Pusat Penelitian dan Pengabdian Masyarakat (P3M) Sekolah Tinggi Perikanan, Jakarta.

Pasaribu BP. 1999. The acoustic survey for the assessment of fish pelagic density in the eastern Mentawai islands. Proc. The 3rd JSPS International seminar on fisheries science in Tropical area, (8) : 252-256. 
Pyle R. 2001. CHAETODONTIDAE. P. 3224-3265. In Carpenter, K.E.; Niem, V.H. (eds). FAO species identification guide for fishery purposes. The living marine resources of the Western Central Pacific. Volume 5. Bony fishes part 3 (Menidae to Pomacentridae).

Russell BC. 2001. NEMIPTERIDAE. P. 3051-3089. In Carpenter, K.E.; Niem, V.H. (eds). FAO species identification guide for fishery purposes. The living marine resources of the Western Central Pacific. Volume 5. Bony fishes part 3 (Menidae to Pomacentridae).

Sugiharto, T. 2009. Bahan Kuliah Statistik 2 : Pengujian Hipotesis. FEUniv. Gunadarma.

Taylor JC, Ebert E. 2012. Mapping coral reef fish schools and aggregations with high-frequency multibeam and split-beam sonars. Proc. Mtgs. Acoust. 17, 070041. doi: 10.1121/1.4772586.

Zare P, Kasatkina SM, Shibaev SV, Fazli H. 2017. In situ acoustic target strength of anchovy kilka (Clupeonella engrauliformis) in the Caspian Sea (Iran). Fisheries Research 186 : 311-318. 